\title{
Current opinion on the role of testosterone in the development of prostate cancer: a dynamic model
}

\author{
Xiaohui Xu ${ }^{1 *}$, Xinguang Chen ${ }^{2}$, Hui Hu${ }^{2}$, Amy B. Dailey $^{3}$ and Brandie D. Taylor ${ }^{1}$
}

\begin{abstract}
Background: Since the landmark study conducted by Huggins and Hodges in 1941, a failure to distinguish between the role of testosterone in prostate cancer development and progression has led to the prevailing opinion that high levels of testosterone increase the risk of prostate cancer. To date, this claim remains unproven.

Presentation of the hypothesis: We present a novel dynamic mode of the relationship between testosterone and prostate cancer by hypothesizing that the magnitude of age-related declines in testosterone, rather than a static level of testosterone measured at a single point, may trigger and promote the development of prostate cancer.

Testing the hypothesis: Although not easily testable currently, prospective cohort studies with populationrepresentative samples and repeated measurements of testosterone or retrospective cohorts with stored blood samples from different ages are warranted in future to test the hypothesis.

Implications of the hypothesis: Our dynamic model can satisfactorily explain the observed age patterns of prostate cancer incidence, the apparent conflicts in epidemiological findings on testosterone and risk of prostate cancer, racial disparities in prostate cancer incidence, risk factors associated with prostate cancer, and the role of testosterone in prostate cancer progression. Our dynamic model may also have implications for testosterone replacement therapy.
\end{abstract}

Keywords: Prostate Cancer, Testosterone, Androgen, Dynamic model

\section{Background}

Prostate cancer $(\mathrm{PCa})$ is the most common cancer and the second leading cause of cancer mortality among American men. In 2014, approximately 233,000 men were diagnosed with PCa and 29,480 PCa-related deaths were reported [1]. Despite high incidence and mortality rates of $\mathrm{PCa}$, the biological mechanism related to the development and progression of PCa remains largely unknown. The prostate is an androgen-regulated organ and there is a long-standing interest in understanding the role of androgens in the development of PCa [2, 3]. Androgens are a class of sex steroid hormones which in males, stimulate and control the development and maintenance of male characteristics including growth and

\footnotetext{
* Correspondence: xiaohui.xu@sph.tamhsc.edu

'Department of Epidemiology \& Biostatistics, School of Public Health, Texas A\&M Health Science Center, 205A SRPH Administration Building|MS 1266, 212 Adriance Lab Road, College Station, TX 77843-1266, USA

Full list of author information is available at the end of the article
}

function of the prostate. Testosterone and its derivative, dihydrotestosterone (DHT), are the two most abundant androgens in males. Approximately $90 \%$ of testosterone is produced by Leydig cells in the testes and an additional $10 \%$ is produced by adrenal glands [4]. DHT is the primary effector androgen and is converted from testosterone by $5 \alpha$-Reductase [4]. DHT becomes biologically active by forming the androgen-receptor complex, which is then translocated from the cytoplasm into the cell nucleus to modulate gene expression [5].

The landmark study by Huggins and Hodges in 1941 suggested a direct correlation between circulating levels of testosterone and PCa progression [6]. It was the first study to show that both progression and regression of $\mathrm{PCa}$ are testosterone-dependent. These findings led to the prevailing hypothesis that elevated androgen levels increase the risk of PCa. However, Huggins and Hodge's study only provided evidence on the role of testosterone 
in the progression of $\mathrm{PCa}$. Therefore, this widely accepted opinion fails to distinguish the role of testosterone in $\mathrm{PCa}$ development. Despite more than 70 years passing since the study was conducted, little progress has been made in understanding the role of testosterone in the development of PCa. Furthermore, evidence from epidemiological studies remains controversial. Some studies supported the prevailing opinion that high testosterone levels are associated with an increased risk of $\mathrm{PCa}$ [7-11] while others have found negative associations between testosterone and risk of PCa [12-15] or no association [16-24]. A pooled analysis of 19 published studies by Roddam et al. (2008) found no statistically significant association between testosterone and the risk of $\mathrm{PCa}$ [25].

All of these studies were guided by a static paradigm, which investigated the relationship between testosterone and $\mathrm{PCa}$ at a single point in cases and controls. Although this type of study design is often more feasible, it is not able to examine the relationship between the change of testosterone with age and PCa risk. Furthermore, these studies did not analyze the role of testosterone in the development of $\mathrm{PCa}$ in the context of individual variation of testosterone level and are insufficient to examine the complex etiological role of testosterone in the carcinogenesis process of PCa. New paradigms are needed to further understand the current data and to guide us to advance PCa research in the future.

Based on evidence from published studies, we propose a dynamic model as a theoretical framework to understand the relationship between testosterone and the development of $\mathrm{PCa}$. As an illustration, we propose a dynamic model to interpret and improve our understanding of the following: the observed age patterns of $\mathrm{PCa}$, the inconsistent findings from published studies, the racial disparities in $\mathrm{PCa}$ incidence, the risk and protective factors for $\mathrm{PCa}$, the role of testosterone in $\mathrm{PCa}$ growth and the use of androgen replacement therapy as primary prevention of $\mathrm{PCa}$.

\section{Presentation of the hypothesis}

Two key components are included in our dynamic model: the magnitude of the age-related declines in testosterone and the individual-based threshold level of testosterone to maintain the normal function of prostate gland. Our model emphasizes that the absolute value of testosterone measured at a single point is not indicative of PCa risk. Instead, the magnitude of the age-related declines in testosterone is a key factor. The risk of $\mathrm{PCa}$ increases when testosterone levels fall below a threshold. As testosterone level falls below the threshold, prostatic cells reach the limit of their compensatory capabilities, thus impairing adaption to lower levels of testosterone and finally triggering the prostatic carcinogenesis process (See Fig. 1).

\section{Testing the hypothesis}

The hypothesis can be tested with prospective cohort studies with longitudinal monitoring testosterone levels in males or retrospective cohort studies with testosterone data available at different ages or stored blood samples collected at different ages available for testing testosterone. With the study design and data, we are able to make a comparison of the patterns of testosterone change over time between cases and controls. For the threshold level, the absolute or relative differences of testosterone levels between young adulthood and at the time of prostate cancer diagnosis may provide important insights about it. In addition, the relative differences of testosterone levels between young adulthood and old age (e.g. 65 years old) may also provide some clues about the threshold level as most of prostate cancer occurs in old age.

\section{Implications of the hypothesis}

The dynamic model and the effect of age on PCa

After the age of 50, the incidence of $\mathrm{PCa}$ increases exponentially with age [26, 27]. Prior studies have yielded rich data regarding the age patterns of testosterone. Testosterone levels are increased in pubertal adolescence, then peak between $30-40$ years, and subsequently falling thereafter at the rate of $2-3 \%$ per year [28-30]. In some men, normal prostate cells develop into tumor cells with age after testosterone level reaches blow a certain level (i.e. individual-based threshold), leading to PCa. Figure 1 illustrates the parallels of PCa development and declining testosterone levels. Studies of age patterns of testosterone levels suggest that only a small proportion of individuals have testosterone levels below the threshold before age 50 . Consequently, PCa risk is very low among this young population. However, after age 50, the proportion of individuals with testosterone levels below the threshold increases dramatically with each. As a result, PCa risk also increases exponentially.

\section{The dynamic model and the role of testosterone in the development of PCa}

Previous research studies have been limited by static models examining the relationship between testosterone levels and PCa. Most published epidemiological studies measured testosterone at a single point in time, which may contribute to the inconsistent findings in the field.

Our dynamic model may help explain conflicting findings. For example, in a group of individuals with PCa who had higher levels of testosterone than others when they were young, their testosterone levels are relatively higher at the time of cancer diagnosis, although they may already have experienced significant declines in testosterone. If such patients are included in research, high testosterone level will be detected as a risk factor for $\mathrm{PCa}$ when compared with controls who have relatively lower peak 


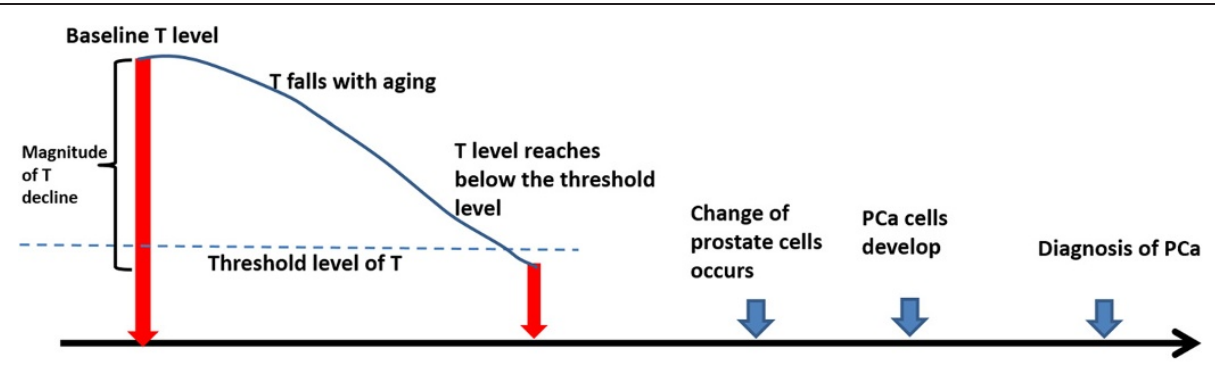

Age

Fig. 1 A hypothetical model illustrates the role of age-related declines in testosterone (T) in thedevelopment of PCa

testosterone at young age (See Fig. 2-Scenario A). In contrast, if a group of individuals with $\mathrm{PCa}$ had lower peak testosterone when they were young, their testosterone level will further decrease by the time of $\mathrm{PCa}$ diagnosis. In this scenario, it is not surprising to observe a negative association between testosterone levels and PCa if these patients are compared with the controls whose dynamic change in testosterone levels follow the pattern for most people in a population (See Fig. 2- Scenario B). If all individuals from Scenario A and Scenario B were analyzed together [25], no association between testosterone levels and $\mathrm{PCa}$ is possible (See Fig. 2- Scenario C).

The dynamic model and PCa racial disparities

Racial disparities in PCa are well documented [31-33]. In the U.S., black males are approximately twice as likely to be diagnosed with PCa compared to white males [34, 35]. However, the determinants of racial disparities in PCa remain unclear. Studies controlling for social impacts of $\mathrm{PCa}$ have attempted to link testosterone levels to the racial differences observed in PCa development [36-45], but findings from these studies are inconsistent [36-46]. With the dynamic model, the increased risk of PCa for blacks could be due to more significant reductions in testosterone levels, relative to that of whites. Evidence from previous studies indicates that testosterone levels in black males declines quicker with age when compared to white men. During young adulthood, testosterone levels are higher in blacks than in whites; but the difference diminishes with age and completely disappears after the age of 60 years of age $[42,47,48]$. Thus, the difference in the magnitude between young and older ages may explain, in part, racial differences in PCa risk.

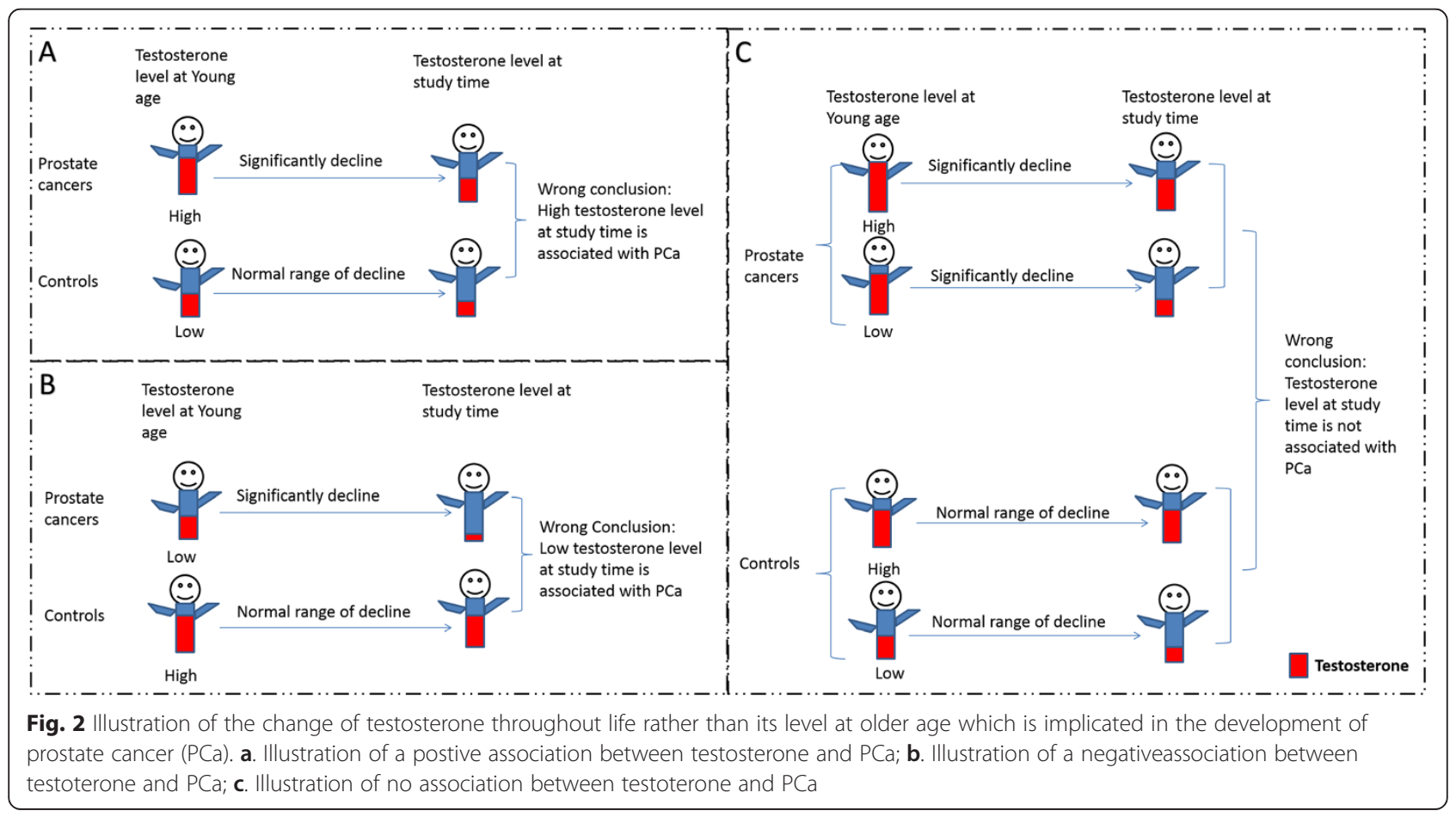


The dynamic model and risk factors for PCa

According to our dynamic model, any factor that affects testosterone levels with age may play an etiological role in the development of PCa. We applied the dynamic model to explain the observed association between selected known risk factors (physical activity, obesity, zinc levels, and vitamin D levels) and PCa by focusing on the ability of risk factors to mediate changes in testosterone levels. This may occur either by slowing down or accelerating the process of the age-related declines in testosterone.

Physical activity and risk of PCa Studies have shown that both occupational and leisurely physical activity can reduce the risk of PCa [49-53]. Many studies have also found that physical activity can increase testosterone levels, particularly among older men [54-57], contradicting the current paradigm [58]. Our dynamic model more fully allows for the idea that physical activity prevents $\mathrm{PCa}$ by increasing testosterone levels, slowing down the age-related declines in testosterone.

Obesity and risk of PCa Evidence from a meta-analysis and systematic reviews suggest that obesity is linked with an increased risk of PCa [59-61], yet explanations for this relationship are weak. Based on our dynamic model, we have at least two possible explanations for this relationship: (1) Being overweight/obese accelerates the age-related declines in testosterone, or (2) overweight/obesity is simply an indicator of accelerated testosterone declines [62]. Findings from epidemiological studies indicate that compared to men with normal weight, obese men have lower testosterone [63, 64]. However, the underlying mechanisms are complex and include many factors such as inactive lifestyle, diet and accelerated testosterone metabolism. For example, studies found that adipose tissue has a strong ability to convert androgen into estrogen [65]. Moreover, the increased androgen-estrogen conversion suppresses the release of luteinizing hormone, reducing the production of testosterone by Leydig cells through a negative hypothalamic-pituitary-gonadal axis feedback loop [66, 67]. Thus, accelerating testosterone metabolism through fat tissues could be one mechanism explaining the mediating role of testosterone in the associations between overweight/obesity and $\mathrm{PCa}$. It is also possible that testosterone levels at baseline are associated with the development of obesity; thus, a detailed time course evaluation of testosterone may be required to fully understand the relationship.

Zinc and risk of PCa Zinc is the most abundant trace mineral in the body $[68,69]$, playing a pivotal role in immune function, antioxidant activities, hormonal function and cellular activities [70-72]. The prostate has the highest concentration of zinc in the male body secreting large amounts of the mineral into prostatic fluid [73]. Thus, there is a growing interest in investigating the role of zinc in the carcinogenesis and pathogenesis of $\mathrm{PCa}$ [74]. Many epidemiological studies have reported marked decreases of zinc levels in PCa tissues versus normal prostate tissues [75-83]. Furthermore, studies suggest that high zinc levels are associated with antitumor effects $[84,85]$. Studies have shown that zinc is important for testosterone production and zinc supplementation can dramatically raise systemic testosterone levels [86-90]. While many biological pathways may be involved in the protective effects of zinc against PCa, the inverse association between zinc and $\mathrm{PCa}$ is consistent with the dynamic model we proposed. According to our model, the protective effect of zinc on PCa could be through its role in slowing down the age-related declines in testosterone.

Vitamin D deficiency and risk of PCa Research indicates that exposure to UV radiation is inversely correlated with PCa incidence and mortality [91-93] and that vitamin D protects against prostate cancer [94-98]. Although the underlying biological mechanisms between vitamin $\mathrm{D}$ and PCa may be complex, our dynamic model provides an explanation. Vitamin D may reduces PCa risk by slowing down the age-related declines in testosterone. Studies have shown that vitamin $\mathrm{D}$ can increase testosterone levels in males [99-102]. In addition, vitamin D deficiency is more prevalent among blacks than other racial groups [103, 104], which may help explain more rapid testosterone declines among blacks, and may also contribute to racial disparities in PCa risk.

In summary, all the factors that are reported to be associated with $\mathrm{PCa}$, as described above, are involved directly or indirectly with levels of testosterone and changes with age. The dynamic model, which proposes that the magnitude of age-related declines in testosterone plays an essential role in the genesis of $\mathrm{PCa}$, may help explain the observed associations between these factors and risk of PCa. As the dynamic model suggests, a risk factor may be in the causal pathway of PCa development through acceleration of agerelated declines in testosterone, while protective factors may slow down the process. Observed relationships between the risk/protective factors discussed above and testosterone are consistent with the dynamic model.

\section{The dynamic model and the role of testosterone in PCa growth}

Different roles of testosterone in the onset and progression of PCa To date, no documented epidemiological studies have distinguished testosterone as a cause of $\mathrm{PCa}$ from a promotor of $\mathrm{PCa}$ growth. One advantage of our dynamic model is that it can be used 
to assess the role of testosterone in the onset of PCa. As the model suggests, the prostatic carcinogenesis may be a process by which the normal prostate cells first adjust themselves to progressive declining testosterone levels at the cellular and receptor levels. As testosterone levels fall below the threshold when normal prostate cells are not able to make additional adjustments without mutations, some of the normal prostate cells may evolve into cancer cells. If additional testosterone is added before reaching the threshold level, it may change the course of the disease. Among the mutated cancer cells, some of them may become testosterone sensitive and increases in testosterone may therefore promote these cancer cells to grow. This notion is supported by evidence that castration (removal of endogenous testosterone) can inhibit PCa progression $[6,105]$, while administration of exogenous testosterone can promote $\mathrm{PCa}$ progression $[106,107]$. Therefore, our dynamic model can also be used to interpret the seemingly conflicted findings that higher testosterone can prevent $\mathrm{PCa}$ onset but promote PCa progression after the disease occurs.

The dynamic model and androgen signaling pathway Androgen receptor (AR) signaling plays an important role in the normal development and homeostasis of the prostate gland $[108,109]$. AR is a nuclear receptor that binds testosterone. The androgen-AR is directly involved in a number of cellular processes that may lead to $\mathrm{PCa}$ genesis, including the regulation of cell cycle, adhesion, apoptosis and extracellular matrix remodeling and metabolism [110]. According to our dynamic model, when testosterone levels reach the threshold, all biochemical processes that are involved with androgen-AR may be altered. Moreover, the testosterone threshold for PCa of an individual may also be determined by the total number and characteristics of AR in normal prostate cells during young adulthood. The hypothesized threshold could be higher for individuals with higher testosterone than those with lower testosterone during young adulthood. Evidence from reported studies tends to support this hypothesis. For example, evidence from randomized controlled trials indicates that most prostate cancers that initially responded to androgen deprivation therapy develop into androgen-independent cancer after a few years of treatment [111-114]. The mechanisms by which tumor cells escape androgen ablation and become independent of the need for androgen might not be to the same as that of normal prostate cells turning into cancer cells. However, they indicate that changes in testosterone may lead to changes at the cellular and molecular levels. Further investigation is needed to confirm these hypotheses by mimicking testosterone decline with aging in vivo or in vitro and studying its effects on changes in prostate cells.

\section{The dynamic model and testosterone replacement therapy}

The question whether testosterone replacement therapy is a risk factor for PCa remains controversial [115]. If confirmed, our dynamic model suggests that testosterone replacement therapy should be provided before testosterone levels drop below the threshold.

Some potential and practice-related questions that also remain include dosage and timing for testosterone replacement therapy to prevent PCa. According to our dynamic model, the purpose of testosterone replacement therapy is to compensate the age-related declines in testosterone and to maintain testosterone levels above the threshold. In our dynamic model, the concept of individual-based hypothesized thresholds of testosterone provides a conceptual framework supporting further research to determine the protocol for individualized PCa prevention using exogenous testosterone. Individual variation is important to understand, as peak testosterone levels may influence threshold levels, and some individuals may have stronger compensatory function.

The timing for testosterone replacement therapy is also important to consider. For primary prevention of $\mathrm{PCa}$, testosterone replacement therapy needs to begin prior to the onset of PCa, when testosterone levels are still above the threshold. If some prostate cells have already become cancer cells, administration of testosterone may promote PCa growth. Given the challenges with determining individual thresholds, longitudinal monitoring of testosterone levels may be another approach to determining the appropriate dosage and timing of testosterone replacement therapy. Examination of testosterone levels in the general population may need to start before age 30 since the incidence of $\mathrm{PCa}$ in autopsy studies has been reported to be as high as $17 \%$ in individuals less than 30 years old [116]. If possible, examination of testosterone levels in prostate tissue may be more informative. When testosterone level falls below a certain percent of the peak level of testosterone, testosterone replacement therapy can restore testosterone levels. However, a recent clinical trial found that intraprostatic testosterone and dihydrotestosterone levels did not significantly increase after administration of supraphysiologic doses of testosterone in patients with symptomatic hypogonadism during the 6-months of follow-up [117]. This finding suggests that the circulating levels of testosterone may be less affected than testosterone levels in the prostate. Nonetheless, the intraprostatic levels of testosterone and dihydrotestosterone declined in the control group, suggesting that treatment is working to increase the T and DHT levels. Without treatment, those with symptomatic hypogonadism may not have stable or slightly higher levels of testosterone and dihydrotestosterone. Testosterone replacement therapy has often been applied to treat 
male hypogonadism. Studies indicate that long-term testosterone replacement appears to be a safe and effective for male hypogonadism [118-121]. Receiving long-term testosterone replacement therapy for hypogonadism men is not associated with an increased risk of PCa [122-124]. In addition, studies also found that men with benign prostate biopsies do not have increased in prostate specific antigen or a significantly increased risk of cancer compared to normal men after one year of testosterone replacement therapy [125]. All findings suggest that testosterone replacement therapy may not be harmful to prostate health. Of course, it remains to be proven that testosterone has any role in prostate carcinogenesis outside of causing growth of pre-existing $\mathrm{PCa}$.

\section{Summary}

$\mathrm{PCa}$ is a killer of millions of men in the United States and across the globe. The dynamic model provides a novel conceptual framework to explain contradictory findings from reported epidemiological studies. Our dynamic model suggests that a significant decline in testosterone levels with age may indicate the role of testosterone in the development of PCa. Our theory suggests a new direction for epidemiological studies to examine the relationship between testosterone levels and risk of $\mathrm{PCa}$ by targeting the magnitude of agerelated declines in testosterone rather than testosterone levels measured at a single point in time. Some fundamental changes in study design are required. If the model is confirmed, it will provide important insights in the etiology and primary prevention of PCa.

\section{Abbreviations}

AR: Androgen receptor; DHT: Dihydrotestosterone; PCa: Prostate cancer; UV: Ultraviolet radiation.

\section{Competing interests}

The authors declare that they have no competing interests.

\section{Authors' contributions}

$X X$ drafted the manuscript based on discussions with $\mathrm{XC}$ and $\mathrm{HH} . \mathrm{XC}, \mathrm{HH}$, and $A D$ revised the manuscript. All authors read and approved the final manuscript.

\section{Acknowledgements}

The authors declare that they have no acknowledgements.

\begin{abstract}
Author details
'Department of Epidemiology \& Biostatistics, School of Public Health, Texas A\&M Health Science Center, 205A SRPH Administration Building | MS 1266, 212 Adriance Lab Road, College Station, TX 77843-1266, USA. ${ }^{2}$ Department of Epidemiology, College of Public Health and Health Professions and College of Medicine, University of Florida, Gainesville, FL, USA. ${ }^{3}$ Health Sciences Department, Gettysburg College, Gettysburg, PA, USA.
\end{abstract}

Received: 14 January 2015 Accepted: 19 October 2015

Published online: 26 October 2015

\section{References}

1. SEER. SEER Stat Fact Sheets: Prostate Cancer. http://seer.cancer.gov/statfacts/ html/prost.html. Accessed on June 28, 20142011.
2. Miller WR, O'Neill JS. The significance of steroid metabolism in human cancer. J Steroid Biochem Mol Biol. 1990;37(3):317-25.

3. Habib FK. Steroid hormones and cancer: IV. Prostate cancer. Eur J Surg Oncol. 1997:23(3):264-8.

4. Carson 3rd C, Rittmaster R. The role of dihydrotestosterone in benign prostatic hyperplasia. Urology. 2003;61(4 Suppl 1):2-7.

5. Marcelli M, Cunningham GR. Hormonal signaling in prostatic hyperplasia and neoplasia. J Clin Endocrinol Metab. 1999:84(10):3463-8.

6. Huggins C, Hodges CV. Studies on prostatic cancer. I. The effect of castration, of estrogen, and of androgen injection on serum phosphatases in metastatic carcinoma of the prostate. Cancer Res. 1941;1:293-7.

7. Barrett-Connor E, Garland C, McPhillips JB, Khaw KT, Wingard DL. A prospective, population-based study of androstenedione, estrogens, and prostatic cancer. Cancer Res. 1990;50(1):169-73.

8. Gann PH, Hennekens CH, Ma J, Longcope C, Stampfer MJ. Prospective study of sex hormone levels and risk of prostate cancer. J Natl Cancer Inst. 1996;88(16):1118-26.

9. Guess HA, Friedman GD, Sadler MC, Stanczyk FZ, Vogelman JH, Imperato-McGinley J, et al. 5 alpha-reductase activity and prostate cancer: a case-control study using stored sera. Cancer Epidemiol Biomarkers Prev. 1997;6(1):21-4.

10. Parsons JK, Carter HB, Platz EA, Wright EJ, Landis P, Metter EJ. Serum testosterone and the risk of prostate cancer: potential implications for testosterone therapy. Cancer Epidemiol Biomarkers Prev. 2005;14(9):2257-60.

11. Travis RC, Key TJ, Allen NE, Appleby PN, Roddam AW, Rinaldi S, et al. Serum androgens and prostate cancer among 643 cases and 643 controls in the European Prospective Investigation into Cancer and Nutrition. Int J Cancer. 2007;121(6):1331-8.

12. Morgentaler A, Bruning 3rd CO, DeWolf WC. Occult prostate cancer in men with low serum testosterone levels. JAMA. 1996;276(23):1904-6.

13. Morgentaler A, Rhoden EL. Prevalence of prostate cancer among hypogonadal men with prostate-specific antigen levels of $4.0 \mathrm{ng} / \mathrm{mL}$ or less. Urology. 2006;68(6):1263-7.

14. Morgentaler A. Testosterone and prostate cancer: an historical perspective on a modern myth. Eur Urol. 2006;50(5):935-9.

15. Morgentaler A. Turning conventional wisdom upside-down: low serum testosterone and high-risk prostate cancer. Cancer. 2011;117(17):3885-8.

16. Hsing AW, Comstock GW. Serological precursors of cancer: serum hormones and risk of subsequent prostate cancer. Cancer Epidemiol Biomarkers Prev. 1993:2(1):27-32.

17. Carter HB, Pearson JD, Metter EJ, Chan DW, Andres R, Fozard JL, et al. Longitudinal evaluation of serum androgen levels in men with and without prostate cancer. Prostate. 1995;27(1):25-31.

18. Nomura AM, Stemmermann GN, Chyou PH, Henderson BE, Stanczyk FZ. Serum androgens and prostate cancer. Cancer Epidemiol Biomarkers Prev. 1996;5(8):621-5.

19. Vatten LJ, Ursin G, Ross RK, Stanczyk FZ, Lobo RA, Harvei S, et al. Androgens in serum and the risk of prostate cancer: a nested case-control study from the Janus serum bank in Norway. Cancer Epidemiol Biomarkers Prev. 1997;6(11):967-9.

20. Dorgan JF, Albanes D, Virtamo J, Heinonen OP, Chandler DW, Galmarini M, et al. Relationships of serum androgens and estrogens to prostate cancer risk: results from a prospective study in Finland. Cancer Epidemiol Biomarkers Prev. 1998;7(12):1069-74.

21. Heikkila R, Aho K, Heliovaara M, Hakama M, Marniemi J, Reunanen A, et al. Serum testosterone and sex hormone-binding globulin concentrations and the risk of prostate carcinoma: a longitudinal study. Cancer. 1999;86(2):312-5.

22. Mohr BA, Feldman HA, Kalish LA, Longcope C, McKinlay JB. Are serum hormones associated with the risk of prostate cancer? Prospective results from the Massachusetts Male Aging Study. Urology. 2001;57(5):930-5.

23. Chen C, Weiss NS, Stanczyk FZ, Lewis SK, DiTommaso D, Etzioni R, et al. Endogenous sex hormones and prostate cancer risk: a case-control study nested within the Carotene and Retinol Efficacy Trial. Cancer Epidemiol Biomarkers Prev. 2003;12(12):1410-6

24. Platz EA, Leitzmann MF, Rifai N, Kantoff PW, Chen YC, Stampfer MJ, et al. Sex steroid hormones and the androgen receptor gene CAG repeat and subsequent risk of prostate cancer in the prostate-specific antigen era. Cancer Epidemiol Biomarkers Prev. 2005;14(5):1262-9.

25. Roddam AW, Allen NE, Appleby P, Key TJ. Endogenous sex hormones and prostate cancer: a collaborative analysis of 18 prospective studies. J Natl Cancer Inst. 2008;100(3):170-83. 
26. Levy IG, Iscoe NA, Klotz LH. Prostate cancer: 1. The descriptive epidemiology in Canada. CMAJ. 1998;159(5):509-13.

27. McDavid K, Lee J, Fulton JP, Tonita J, Thompson TD. Prostate cancer incidence and mortality rates and trends in the United States and Canada. Public Health Rep. 2004;119(2):174-86.

28. Baker HW, Burger HG, de Kretser DM, Hudson B, O'Connor S, Wang C, et al. Changes in the pituitary-testicular system with age. Clin Endocrinol (Oxf). 1976;5(4):349-72

29. Feldman HA, Longcope C, Derby CA, Johannes CB, Araujo AB, Coviello AD, et al. Age trends in the level of serum testosterone and other hormones in middle-aged men: longitudinal results from the Massachusetts male aging study. J Clin Endocrinol Metab. 2002;87(2):589-98.

30. Ferrini RL, Barrett-Connor E. Sex hormones and age: a cross-sectional study of testosterone and estradiol and their bioavailable fractions in community-dwelling men. Am J Epidemiol. 1998;147(8):750-4.

31. Berger AD, Satagopan J, Lee P, Taneja SS, Osman I. Differences in clinicopathologic features of prostate cancer between black and white patients treated in the 1990s and 2000s. Urology. 2006;67(1):120-4.

32. Jemal A, Siegel R, Xu J, Ward E. Cancer statistics, 2010. CA Cancer J Clin. 2010;60(5):277-300.

33. Mullins CD, Onukwugha E, Bikov K, Seal B, Hussain A. Health disparities in staging of SEER-medicare prostate cancer patients in the United States. Urology. 2010;76(3):566-72.

34. Bock CH, Powell I, Kittles RA, Hsing AW, Carpten J. Racial disparities in prostate cancer incidence, biochemical recurrence, and mortality. Prostate Cancer. 2011;2011:716178.

35. American Cancer Society. Cancer Facts and Figures 2014. Atlanta: American Cancer Society; 2014

36. Cheng I, Yu MC, Koh WP, Pike MC, Kolonel LN, Henderson BE, et al. Comparison of prostate-specific antigen and hormone levels among men in Singapore and the United States. Cancer Epidemiol Biomarkers Prev. 2005;14(7):1692-6.

37. Ellis L, Nyborg H. Racial/ethnic variations in male testosterone levels: a probable contributor to group differences in health. Steroids. 1992;57(2):72-5

38. Ettinger B, Sidney S, Cummings SR, Libanati C, Bikle DD, Tekawa IS, et al. Racial differences in bone density between young adult black and white subjects persist after adjustment for anthropometric, lifestyle, and biochemical differences. J Clin Endocrinol Metab. 1997;82(2):429-34.

39. Litman HJ, Bhasin S, Link CL, Araujo AB, McKinlay JB. Serum androgen levels in black, Hispanic, and white men. J Clin Endocrinol Metab. 2006:91(11):4326-34

40. Orwoll ES, Nielson CM, Labrie F, Barrett-Connor E, Cauley JA, Cummings SR, et al. Evidence for geographical and racial variation in serum sex steroid levels in older men. J Clin Endocrinol Metab. 2010;95(10):E151-160.

41. Rohrmann S, Nelson WG, Rifai N, Brown TR, Dobs A, Kanarek N, et al. Serum estrogen, but not testosterone, levels differ between black and white men in a nationally representative sample of Americans. J Clin Endocrinol Metab. 2007;92(7):2519-25.

42. Ross R, Bernstein L, Judd H, Hanisch R, Pike M, Henderson B. Serum testosterone levels in healthy young black and white men. J Natl Cancer Inst. 1986;76(1):45-8.

43. Winters SJ, Brufsky A, Weissfeld J, Trump DL, Dyky MA, Hadeed V. Testosterone, sex hormone-binding globulin, and body composition in young adult African American and Caucasian men. Metabolism. 2001;50(10):1242-7.

44. Wright NM, Renault J, Willi S, Veldhuis JD, Pandey JP, Gordon L, et al. Greater secretion of growth hormone in black than in white men: possible factor in greater bone mineral density-a clinical research center study. J Clin Endocrinol Metab. 1995;80(8):2291-7.

45. Wu AH, Whittemore AS, Kolonel LN, John EM, Gallagher RP, West DW, et al. Serum androgens and sex hormone-binding globulins in relation to lifestyle factors in older African-American, white, and Asian men in the United States and Canada. Cancer Epidemiol Biomarkers Prev. 1995;4(7):735-41.

46. Gapstur SM, Gann PH, Kopp P, Colangelo L, Longcope C, Liu K. Serum androgen concentrations in young men: a longitudinal analysis of associations with age, obesity, and race. The CARDIA male hormone study. Cancer Epidemiol Biomarkers Prev. 2002;11(10):1041-7.

47. Hu H, Odedina FT, Reams RR, Lissaker CTK, Xu X. Racial Differences in Age-Related Variations of Testosterone Levels among US Males: Potential Implications for Prostate Cancer and Personalized Medication. J Racial Ethn Health Disparities. 2015;2:69-76.
48. Nyborg H. Hormones, Sex, and Society: The Science of Physicology: Praeger 1994

49. Discacciati A, Wolk A. Lifestyle and dietary factors in prostate cancer prevention. Recent Results Cancer Res. 2014;202:27-37.

50. Orsini N, Bellocco R, Bottai M, Pagano M, Andersson SO, Johansson JE, et al. A prospective study of lifetime physical activity and prostate cancer incidence and mortality. Br J Cancer. 2009;101(11):1932-8

51. Patel AV, Rodriguez C, Jacobs EJ, Solomon L, Thun MJ, Calle EE. Recreational physical activity and risk of prostate cancer in a large cohort of U.S. men. Cancer Epidemiol Biomarkers Prev. 2005;14(1):275-9.

52. Oliveria SA, Lee IM. Is exercise beneficial in the prevention of prostate cancer? Sports Med. 1997;23(5):271-8.

53. Young-McCaughan S. Potential for prostate cancer prevention through physical activity. World J Urol. 2012;30(2):167-79.

54. Kraemer WJ, Hakkinen K, Newton RU, Nindl BC, Volek JS, McCormick M, et al. Effects of heavy-resistance training on hormonal response patterns in younger vs. older men. J Appl Physiol. 1999;87(3):982-92.

55. Craig BW, Brown R, Everhart J. Effects of progressive resistance training on growth hormone and testosterone levels in young and elderly subjects. Mech Ageing Dev. 1989;49(2):159-69.

56. Hayes LD, Grace FM, Sculthorpe N, Herbert P, Kilduff LP, Baker JS. Does chronic exercise attenuate age-related physiological decline in males? Res Sports Med. 2013;21(4):343-54.

57. Khoo J, Tian HH, Tan B, Chew K, Ng CS, Leong D, et al. Comparing effects of low- and high-volume moderate-intensity exercise on sexual function and testosterone in obese men. J Sex Med. 2013;10(7):1823-32.

58. Heitkamp HC, Jelas I. Physical activity for primary prevention of prostate cancer. Possible mechanisms. Der Urologe Ausg A. 2012;51(4):527-32.

59. Allott EH, Masko EM, Freedland SJ. Obesity and prostate cancer: weighing the evidence. Eur Urol. 2013;63(5):800-9.

60. Buschemeyer 3rd WC, Freedland SJ. Obesity and prostate cancer: epidemiology and clinical implications. Eur Urol. 2007;52(2):331-43.

61. Maclnnis RJ, English DR. Body size and composition and prostate cancer risk: systematic review and meta-regression analysis. Cancer Causes Control. 2006;17(8):989-1003.

62. Kelly DM, Jones TH. Testosterone: a metabolic hormone in health and disease. J Endocrinol. 2013;217(3):R25-45.

63. Jensen TK, Andersson AM, Jorgensen N, Andersen AG, Carlsen E, Petersen $\mathrm{JH}$, et al. Body mass index in relation to semen quality and reproductive hormones among 1,558 Danish men. Fertil Steril. 2004;82(4):863-70.

64. Couillard C, Gagnon J, Bergeron J, Leon AS, Rao DC, Skinner JS, et al. Contribution of body fatness and adipose tissue distribution to the age variation in plasma steroid hormone concentrations in men: the HERITAGE Family Study. J Clin Endocrinol Metab. 2000;85(3):1026-31.

65. Nimrod A, Ryan KJ. Aromatization of androgens by human abdominal and breast fat tissue. J Clin Endocrinol Metab. 1975:40(3):367-72.

66. Hayes FJ, Seminara SB, Decruz S, Boepple PA, Crowley Jr WF. Aromatase inhibition in the human male reveals a hypothalamic site of estrogen feedback. J Clin Endocrinol Metab. 2000;85(9):3027-35.

67. Finkelstein JS, O'Dea LS, Whitcomb RW, Crowley Jr WF. Sex steroid control of gonadotropin secretion in the human male. II. Effects of estradiol administration in normal and gonadotropin-releasing hormone-deficient men. J Clin Endocrinol Metab. 1991;73(3):621-8.

68. Frederickson CJ, Suh SW, Silva D, Frederickson CJ, Thompson RB. Importance of zinc in the central nervous system: the zinc-containing neuron. J Nutr. 2000;130(5S Suppl):1471S-83S.

69. Andreini C, Banci L, Bertini I, Rosato A. Counting the zinc-proteins encoded in the human genome. J Proteome Res. 2006;5(1):196-201.

70. Frederickson CJ, Koh JY, Bush Al. The neurobiology of zinc in health and disease. Nat Rev Neurosci. 2005;6(6):449-62.

71. Maret W. Zinc and human disease. Met lons Life Sci. 2013;13:389-414.

72. Prasad AS. Zinc: an overview. Nutrition. 1995;11(1 Suppl):93-9.

73. Okamura T, Fujio K, Shibuya M, Sumitomo S, Shoda H, Sakaguchi S, et al. CD4+CD25-LAG3+ regulatory T cells controlled by the transcription factor Egr-2. Proc Natl Acad Sci U S A. 2009;106(33):13974-9.

74. Costello LC, Franklin RB. Novel role of zinc in the regulation of prostate citrate metabolism and its implications in prostate cancer. Prostate. 1998;35(4):285-96.

75. Darago A, Sapota A, Matych J, Nasiadek M, Skrzypinska-Gawrysiak M, Kilanowicz A. The correlation between zinc and insulin-like growth factor 1 (IGF-1), its binding protein (IGFBP-3) and prostate-specific antigen (PSA) in prostate cancer. Clin Chem Lab Med. 2011;49(10):1699-705. 
76. Goel T, Sankhwar SN. Comparative study of zinc levels in benign and malignant lesions of the prostate. Scand J Urol Nephrol. 2006;40(2):108-12.

77. Whelan P, Walker BE, Kelleher J. Zinc, vitamin A and prostatic cancer Br J Urol. 1983:55(5):525-8.

78. Brys M, Nawrocka AD, Miekos E, Zydek C, Foksinski M, Barecki A, et al. Zinc and cadmium analysis in human prostate neoplasms. Biol Trace Elem Res. 1997;59(1-3):145-52.

79. Feustel A, Wennrich R, Steiniger D, Klauss P. Zinc and cadmium concentration in prostatic carcinoma of different histological grading in comparison to normal prostate tissue and adenofibromyomatosis (BPH). Urol Res. 1982;10(6):301-3.

80. Feustel A, Wennrich R. Zinc and cadmium in cell fractions of prostatic cancer tissues of different histological grading in comparison to $\mathrm{BPH}$ and normal prostate. Urol Res. 1984;12(2):147-50.

81. Marczynska A, Kulpa J, Lenko J. The concentration of zinc in relation to fundamental elements in the diseased human prostate. Int Urol Nephrol. 1983;15(3):257-65

82. Schrodt GR, Hall T, Whitmore Jr WF. The Concentration of Zinc in Diseased Human Prostate Glands. Cancer. 1964;17:1555-66.

83. Karimi G, Shahar S, Homayouni N, Rajikan R, Abu Bakar NF, Othman MS. Association between trace element and heavy metal levels in hair and nail with prostate cancer. Asian Pac J Cancer Prev. 2012;13(9):4249-53.

84. Costello LC, Franklin RB. The clinical relevance of the metabolism of prostate cancer; zinc and tumor suppression: connecting the dots. Mol Cancer. 2006:5:17.

85. Franklin RB, Costello LC. Zinc as an anti-tumor agent in prostate cancer and in other cancers. Arch Biochem Biophys. 2007;463(2):211-7.

86. Prasad AS, Mantzoros CS, Beck FW, Hess JW, Brewer GJ. Zinc status and serum testosterone levels of healthy adults. Nutrition. 1996;12(5):344-8.

87. Hartoma R. Serum testosterone compared with serum zinc in man. Acta Physiol Scand. 1977;101(3):336-41.

88. Martin GB, White CL, Markey CM, Blackberry MA. Effects of dietary zinc deficiency on the reproductive system of young male sheep: testicular growth and the secretion of inhibin and testosterone. J Reprod Fertil. 1994:101(1):87-96.

89. Prasad AS, Abbasi AA, Rabbani P, DuMouchelle E. Effect of zinc supplementation on serum testosterone level in adult male sickle cell anemia subjects. Am J Hematol. 1981;10(2):119-27.

90. Netter A, Hartoma R, Nahoul K. Effect of zinc administration on plasma testosterone, dihydrotestosterone, and sperm count. Arch Androl. 1981;7(1):69-73.

91. Hanchette $\mathrm{CL}$, Schwartz GG. Geographic patterns of prostate cancer mortality. Evidence for a protective effect of ultraviolet radiation. Cancer. 1992:70(12):2861-9.

92. Schwartz GG, Hanchette CL. UV, latitude, and spatial trends in prostate cancer mortality: all sunlight is not the same (United States). Cancer Causes Control. 2006;17(8):1091-101.

93. John EM, Schwartz GG, Koo J, Van Den Berg D, Ingles SA. Sun exposure, vitamin $\mathrm{D}$ receptor gene polymorphisms, and risk of advanced prostate cancer. Cancer Res. 2005:65(12):5470-9.

94. Schwartz GG. Vitamin D and the epidemiology of prostate cancer. Semin Dial. 2005;18(4):276-89.

95. Giovannucci E. The epidemiology of vitamin D and cancer incidence and mortality: a review (United States). Cancer Causes Control. 2005:16(2):83-95.

96. Schwartz GG. Vitamin D and intervention trials in prostate cancer: from theory to therapy. Ann Epidemiol. 2009;19(2):96-102.

97. Chen TC, Holick MF. Vitamin D and prostate cancer prevention and treatment. Trends Endocrinol Metab. 2003:14(9):423-30.

98. Gilbert R, Metcalfe C, Fraser WD, Donovan J, Hamdy F, Neal DE, et al. Associations of circulating 25 -hydroxyvitamin D with prostate cance diagnosis, stage and grade. Int J Cancer. 2012;131(5):1187-96.

99. Wehr E, Pilz S, Boehm BO, Marz W, Obermayer-Pietsch B. Association of vitamin D status with serum androgen levels in men. Clin Endocrinol (Oxf) 2010:73(2):243-8

100. Pilz S, Frisch S, Koertke H, Kuhn J, Dreier J, Obermayer-Pietsch B, et al. Effect of vitamin D supplementation on testosterone levels in men. Horm Metab Res. 2011;43(3):223-5.

101. Hofer D, Munzker J, Schwetz V, Ulbing M, Hutz K, Stiegler $P$, et al. Testicular synthesis and vitamin D action. J Clin Endocrinol Metab. 2014;99:3766-73.
102. Nimptsch K, Platz EA, Willett WC, Giovannucci E. Association between plasma 25-OH vitamin D and testosterone levels in men. Clin Endocrinol (Oxf). 2012;77(1):106-12.

103. Harris SS. Vitamin D and African Americans. J Nutr. 2006:136(4):1126-9.

104. Harris SS. Does vitamin D deficiency contribute to increased rates of cardiovascular disease and type 2 diabetes in African Americans? Am J Clin Nutr. 2011;93(5):1175S-8S.

105. Huggins C, Stevens R, Hodges C. Studies on prostatic cancer. II. The effects of castration on advanced carcinoma of the prostate gland. Arch Surg. 1941;43(2):209-23.

106. Fowler Jr JE, Whitmore Jr WF. The response of metastatic adenocarcinoma of the prostate to exogenous testosterone. J Urol. 1981;126(3):372-5.

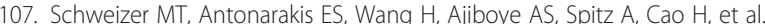
Effect of bipolar androgen therapy for asymptomatic men with castration-resistant prostate cancer: Results from a pilot clinical study. Sci Transl Med. 2015;7(269):269ra2

108. Roy AK, Lavrovsky Y, Song CS, Chen S, Jung MH, Velu NK, et al. Regulation of androgen action. Vitam Horm. 1999;55:309-52.

109. Lindzey J, Kumar MV, Grossman M, Young C, Tindall DJ. Molecular mechanisms of androgen action. Vitam Horm. 1994:49:383-432.

110. Heinlein CA, Chang C. Androgen receptor in prostate cancer. Endocr Rev. 2004:25(2):276-308.

111. Lane TM, Ansell W, Farrugia D, Wilson P, Williams G, Chinegwundoh F, et al. Long-term outcomes in patients with prostate cancer managed with intermittent androgen suppression. Urol Int. 2004;73(2):117-22.

112. Taplin ME, Bubley GJ, Shuster TD, Frantz ME, Spooner AE, Ogata GK, et al. Mutation of the androgen-receptor gene in metastatic androgenindependent prostate cancer. N Engl J Med. 1995;332(21):1393-8.

113. Xu B, Tang G, Xiao C, Wang L, Yang Q, Sun Y. Androgen deprivation therapy induces androgen receptor-dependent upregulation of Egr1 in prostate cancers. Int J Clin Exp Pathol. 2014;7(6):2883-93.

114. Neschadim A, Summerlee AJ, Silvertown JD. Targeting the relaxin hormonal pathway in prostate cancer. Int J Cancer. 2015:137(10):2287-95.

115. Ramasamy R, Fisher ES, Schlegel PN. Testosterone replacement and prostate cancer. Indian J Urol. 2012;28(2):123-8.

116. Bell KJ, Del Mar C, Wright G, Dickinson J, Glasziou P. Prevalence of incidental prostate cancer: A systematic review of autopsy studies. Int J Cancer. 2015;137:1749-57.

117. Marks LS, Mazer NA, Mostaghel E, Hess DL, Dorey FJ, Epstein Jl, et al. Effect of testosterone replacement therapy on prostate tissue in men with lateonset hypogonadism: a randomized controlled trial. JAMA. 2006;296(19):2351-61.

118. Hajjar RR, Kaiser FE, Morley JE. Outcomes of long-term testosterone replacement in older hypogonadal males: a retrospective analysis. J Clin Endocrinol Metab. 1997:82(11):3793-6.

119. Sih R, Morley JE, Kaiser FE, Perry 3rd HM, Patrick P, Ross C. Testosterone replacement in older hypogonadal men: a 12-month randomized controlled trial. J Clin Endocrinol Metab. 1997;82(6):1661-7.

120. Wang C, Swerdloff RS, Iranmanesh A, Dobs A, Snyder PJ, Cunningham G, et al. Transdermal testosterone gel improves sexual function, mood, muscle strength, and body composition parameters in hypogonadal men. J Clin Endocrinol Metab. 2000;85(8):2839-53.

121. Wang C, Eyre DR, Clark R, Kleinberg D, Newman C, Iranmanesh A, et al. Sublingual testosterone replacement improves muscle mass and strength, decreases bone resorption, and increases bone formation markers in hypogonadal men-a clinical research center study. J Clin Endocrinol Metab. 1996;81(10):3654-62.

122. Haider A, Zitzmann M, Doros G, Isbarn H, Hammerer P, Yassin A. Incidence of Prostate Cancer in Hypogonadal Men Receiving Testosterone Therapy: Observations from Five Year-median Follow-up of Three Registries. J Urol. 2014;193:80-6.

123. Svetec DA, Canby ED, Thompson IM, Sabanegh Jr ES. The effect of parenteral testosterone replacement on prostate specific antigen in hypogonadal men with erectile dysfunction. J Urol. 1997;158(5):1775-7.

124. Gooren LJ. A ten-year safety study of the oral androgen testosterone undecanoate. J Androl. 1994;15(3):212-5

125. Rhoden EL, Morgentaler A. Testosterone replacement therapy in hypogonadal men at high risk for prostate cancer: results of 1 year of treatment in men with prostatic intraepithelial neoplasia. J Urol. 2003:170(6 Pt 1):2348-51 